\title{
Morphological Observations on Capitulum Initiation and Floret Development of Garland Chrysanthemum (Chrysanthemum coronarium L.)
}

\author{
Yulian, Yukihiro Fujime and Nobuyuki Okuda \\ Faculty of Agriculture, Kagawa University, Miki, Kagawa 761-07
}

\begin{abstract}
Summary
Morphological properties of capitulum initiaton and floret development of garland chrysanthemum (Chrysanthemum coronarium L.) were observed with a scanning electron microscope (SEM). Sixteen cultivars varying in flowering time were used. The flowering process was classified into 10 stages. A capitulum was initiated from stage 2 (early involucre forming-stage). The differentiation between ray and disc florets occurred at stage 5 (late floret forming-stage). Disc florets has a pistil and five stamens. Disc florets covered the entire surface of receptacle except for one or two layers of ray floret which are located on the periphery of the receptacle between the disc florets and the involucres. A ray florets has a pistil, but no stamen.

There were cultivar differences in capitulum size, numbers of ray and disc florets, and involucres. The diameter of the capitulum ranged from $71.0 \pm 0.0 \mathrm{~mm}$ to $42.0 \pm 6.2 \mathrm{~mm}$; the number of ray florets per capitulum ranged from to $23.7 \pm 5.4$ to $14.2 \pm 0.5$; where the range of disc florets was from to $478.0 \pm 0.0$ to $276.2 \pm 44.8$. The number of bracts (involucres) per capitulum ranged from $41.0 \pm 0.0$ to $27.50 \pm 5.0$.

Individual cultivars differed in flowering response between spring and autumn. In the spring, budding in all cultivars occurred earlier than that in autumn. Capitulum of 'Kairyo chuba satoyutaka', 'Tatsunami', and 'Otafuku-A' became visible 10, 15, and 35 days after planting, respectively. In autumn, however, capitulum initation of 'Kairyo chuba satoyutaka' occurred 70 days after planting.

The number of nodes from the cotyledon to capitulum in the spring was significantly fewer than that formed in the autumn. The node number of 'Kairyo chuba satoyutaka' was 32.8 in the spring, and 54.7 in the autumn.
\end{abstract}

\section{Introduction}

Garland chrysanthemum (Chrysanthemum coronarium $\mathrm{L}$.) is an annual plant which originated in the Mediterranean region and introduced to other areas of Europe, Africa, and Asia. Its names are chop suey greens in North America and crown daisy in Europe (Bailey, 1949; Herklots, 1972; Larkcom, 1991; Park, 1980). It developed as a leafy vegetable in Japan, China, and South-East Asia. It is a popular leafy vegetable that is widely used in many traditional Japanese dishes.

Received for publication 19 June 1995.

Studies on flowering and branching of garland chrysanthemum (Chrysanthemum coronarium L.) (1)

A part of this study was presented at the 1994 Spring Meeting of the Japan. Soc. Hort. Sci.
The relation among earliness to flower, plant form, and leaf lobeness has not been investigated. Garland chrysanthemum is traditionally divided into three types, according to plant form and leaf lobeness. Shinohara (1984) reported that small leaf types are usually deeply lobed and flowers early. Clones with intermediate leaf size are characteristically moderately lobed and also flowers early. The large leaf types normally have shallow lobes and flowers late. Iwami et al. (1983) reported that flowering of garland chrysanthemum is promoted by long day, whereas Mochizuki and Hiraoka (1978) reported that continuous lighting also promoted an initiation of flower bud. These reports indicate that flower buds are induced under a long photoperiod but Javier (1990) reported that flowering was promoted by short days 
in Taiwan. Taiwan is located in latitude of $25^{\circ}$, where the daylength ranges from $10.3 \sim 13.4 \mathrm{hr}$. With such conflicting observations, the inductive daylength condition for flowering in garland chry. santhemum is questionable. Iwami et al. (1983) reported that the germinating seeds exposed to low temperature form a capitulum earlier than the unchilled control, but they used only one cultivar. Hence, the inductive condition necessary to promote early capitulum initiation in this species, with respect to temperature is still unknown.

There are a number of investigations on floral development in many species; Apium graveolens L. var. rapaceum (Mill.) DC. (Booij et al., 1992). Tanacetum cinerariaefolium L. (Brown and Menary, 1994), broccoli and cauliflower (Fujime, 1983), komatsuna and shun-giku (Iwami et al., 1983), Chinese vegetables (Kakibuchi, 1994) and Japanese radish (Sagwansupyakorn et al., 1985). However, there is only one morphological report on flower bud initiation and differentiation of garland chrysanthemum (Iwami et al., 1983). They showed a sketch of that flower bud, but did not explain the morphological properties of florets. Garland chrysanthemum has an inflorescence named capitulum (Yulian et al., 1994a) consisting of an involucre (fused bracts), one or two whorls of ray florets, and disc florets covering the rest of receptacle. However, the origin and the differentiation of the involucre, ray florets, and disc florets were not investigated morphologically. Hence, how cultivar and seasonal differences affect the flowering response in the species are still unknown.

In this study, the floral development of garland chrysanthemum, morphological characteristics of the capitulum, ray and disc florets using scanning electron microscope (SEM) were investigated. Furthermore, cultivar differences in capitulum size, numbers of ray florets, disc florets and involucre in plants grown in spring and autumn were also investigated.

\section{Materials and Methods}

\section{Experiment 1 (Floral stages)}

Seeds of garland chrysanthemum 'Kairyo chuba satoyutaka' (Sakata Seed Co.) were germinated on moist filter paper in a growth chamber (NK System Biotron Type LH-200-RD) provided with 14 hr daylength and rest at $23{ }^{\circ} \mathrm{C}$ on June $2,1992$.
Two days later the germinating seeds were sown in seeding boxes $(28 \mathrm{~cm} \times 52 \mathrm{~cm})$ containing soilsand-vermiculite $(5: 2: 2$ by volume). Seedings with three to four unfolded leaves were transplanted to $9 \mathrm{~cm}$ diameter plastic pots and placed in a greenhouse under natural photoperiod and maintained at $20{ }^{\circ} \mathrm{C}$. When seedlings had six to seven leaves, they were planted in the open field on July 1 , spaced at $25 \mathrm{~cm} \times 25 \mathrm{~cm}$. After applying basal fertilizer IB-604 $3.6 \mathrm{~kg} /$ row (N32, P20, K28 kg/10 a) and lime $1.8 \mathrm{~kg} / \mathrm{row}(99.2 \mathrm{~kg} / 10 \mathrm{a})$, the two rows, $4 \mathrm{~m}$ in length and $1.2 \mathrm{~m}$ width, were covered with plastic mulch; the plants were cultivated as usual.

Beginning on July 1, 12 plants were sampled at 7 -day intervals, and their shoot tips fixed in formalin-acetic acid-alcohol (FAA solution). The shoot tips were dissected under a stereoscopic microscope and the number of leaf primordia, diameter of capitulum, and floral stages were identified. The following fixing procedure, developed by Fujime (1983), was used. The shoot tips were fixed in $4 \%$ solution of glutaraldehyde in $0.1 \mathrm{M}$ phosphate buffer $\left(\mathrm{pH} \mathrm{7.4)}\right.$ at $5{ }^{\circ} \mathrm{C}$ for $24 \mathrm{hr}$. The samples were rinsed 3 times in the phosphate buffer and post fixed with $1.6 \%$ osmium solution in the same buffer at $5{ }^{\circ} \mathrm{C}$ for $3 \mathrm{hr}$. The materials were dehydrated sequentially in the ethanol series, $15 \%, 30 \%, 50 \%, 70 \%$ for 30 minutes, and then in $85 \%$ and $95 \%$ for $1 \mathrm{hr}$ each and $100 \%$ for $24 \mathrm{hr}$. The alcohol was exchanged in series with $50 \%$ and $100 \%$ iso-amyl acetate solutions for 12 hr. The shoot tip samples were then dried in a Hitachi Critical Point Drier ( $\mathrm{HCP}-1)$, mounted on SEM stubs with a drop of silver paste, sputtered with gold pallidium in a RMC-eiko corp. ion coater, and photographed with on a Hitachi S-800 Scanning electron microscope at $5-8 \mathrm{kV}$ accelerating voltage.

\section{Experiment 2 (Cultivar difference)}

Seeds of 16 cultivars (see Table 2) were germinated on moist filter paper in a growth chamber provided with $14 \mathrm{hr}$ photoperiod and rest at 23 ${ }^{\circ} \mathrm{C}$ in May and September of 1991; and in April and September of 1992. Plants were grown in a greenhouse under natural photoperiod. Minimum air temperature was maintained at $20{ }^{\circ} \mathrm{C}$. When the seedlings had six to seven leaves, they were planted in the field. The plots were fertilized as in 
Exp. 1. Twelve plants of each cultivar were cultivated as usual and the date of budding and anthesis and number of nodes from cotyledon to the capitulum were recorded for the four plantings. Because budding and anthesis occurred in autumn which is uncommon, the experiment was stopped 70 days after planting. Shoot tips were sampled and observed under a light microscope.

\section{Results and Discussion}

\section{Floral stages}

The flowering process was classified into 10 stages. Vegetative stage is characterized by a conical shoot apex with its leaf primordia (Fig. 1-0). For other species of composite, Tanacetum cinerariaefolium L., as described by Brown and Menary (1994), a slightly concave apical shape may occur during vegetative growth, especially when the meristem slightly enlarges owing to the initiation of leaf primordia.

At the dome forming-stage (Fig. 1-1), the shoot apex forms a dome whose diameter increases steadily and becomes a highly arched, nearly round receptacle.

At this early involucre-forming stage (Fig. 1-2), the primordia of involucral scales (bract or modified leaf) are initiated at the periphery of the dome; a first evidence that the capitulum is forming. 'Kariyo chuba satoyutaka' initiated a capitulum on July 29 (Fig. 2) when more than $50 \%$ of the plants reached late involucre-forming stage. Each cultivar differ as to when flower bud or capitulum differentiation and anthesis occur. The present aim of commercial production of garland chrysanthemum in Japan is to provide a stable, constant supply throughout the year, especially in summer. Morishita et al. (1987) reported using 22 cultivars that their growth and development were variable by cropping seasons.

At this late involucre-forming stage (Fig. 1-3), the bract primordia (involucre) appears and elongate around the base of the receptacle. These involucre initials are located just above the last leaf, their arrangement is similar to that of the leaf primordia at vegetative stage but is more compact. Floret initials are not yet visible during this stage.

At the early floret-forming stage (Fig. 1-4), 2 3 layers of florets are differentiated on the base of the dome. Two types of florets: disc and ray florets appear but they can not be identified as such as this stage. The disc florets develop further (Fig. 3) with the acropetal appearance of the corolla and five stamen primordia. The corolla primordium of disc floret has a small lobe on the margin.

At this late floret-forming stage (Fig. 1-5), the

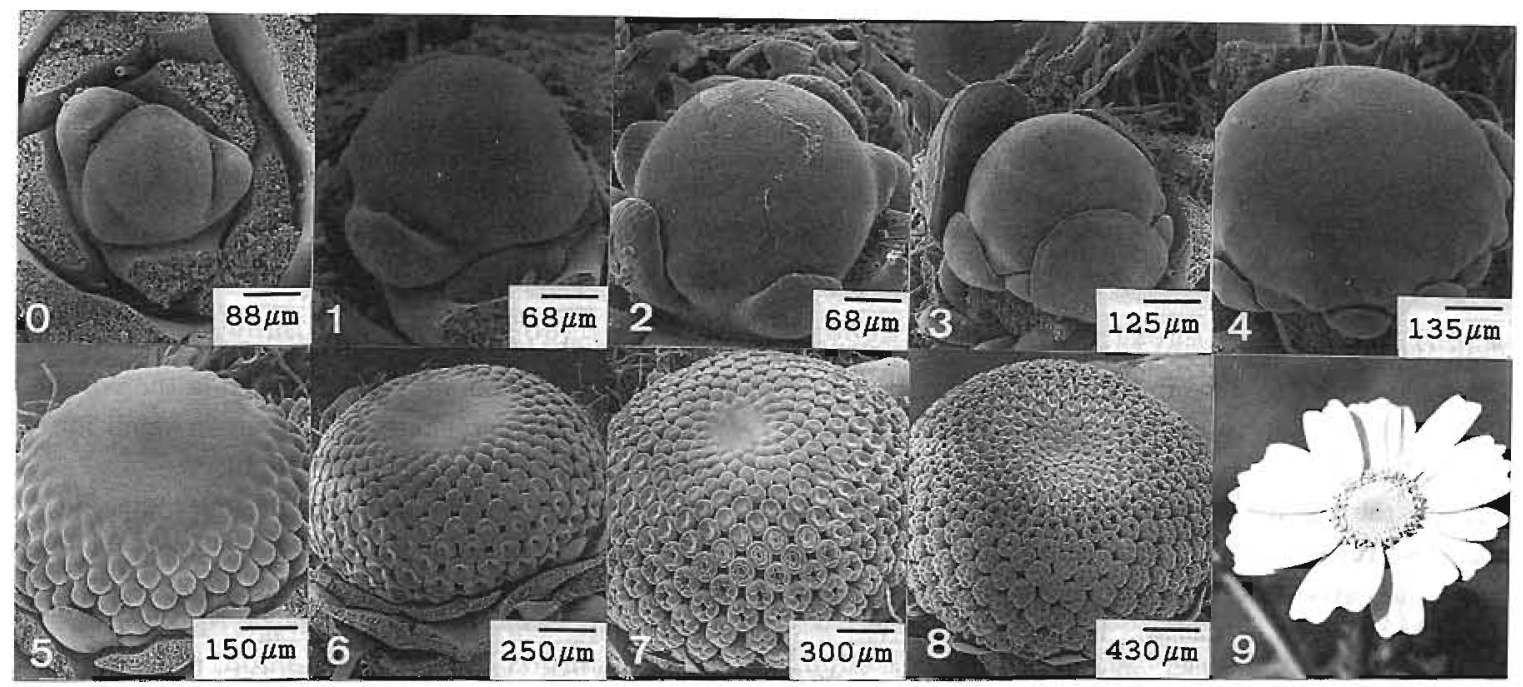

Fig. 1. Photomicrographs showing the floral stages of garland chrysanthemum. O: Vegetative stage. 1: Dome-forming stage. 2: Early involucre-forming stage. 3: Late involucre-forming stage. 4: Early floret-forming stage. 5: Late floret-forming stage. 6: Early corolla-forming stage. 7: Intermediate corolla-forming stage. 8: Late corolla-forming stage. 9: Anthesis. 


\begin{tabular}{|c|c|c|c|c|c|c|c|c|c|c|}
\hline \multirow[b]{2}{*}{$\begin{array}{l}\text { Date of } \\
\text { sampling }\end{array}$} & \multicolumn{10}{|c|}{ Floral stages } \\
\hline & 0 & 1 & 2 & 3 & 4 & 5 & 6 & 7 & 8 & 9 \\
\hline 7. 1 & $8888^{\circ}$ & $\infty$ & 0 & & & & & & & \\
\hline 7. 8 & $\infty$ & 8000 & $\infty$ & & & & & & & \\
\hline 7. 15 & & 8898 & $\infty$ & & 0 & & & & & \\
\hline 7. 22 & & 8800 & & $\infty$ & & $\infty$ & & & & \\
\hline 7. 29 & & $\infty 00$ & & $\infty$ & $\infty 000$ & $\circ$ & & & & \\
\hline 8. 6 & & & & & & 0 & $\infty$ & $\infty$ & $\infty 0000$ & $\infty$ \\
\hline
\end{tabular}

Fig. 2. Floral stages in 'Kairyo chuba satoyutaka' in spring of 1992. z: Refer to Fig. 1.

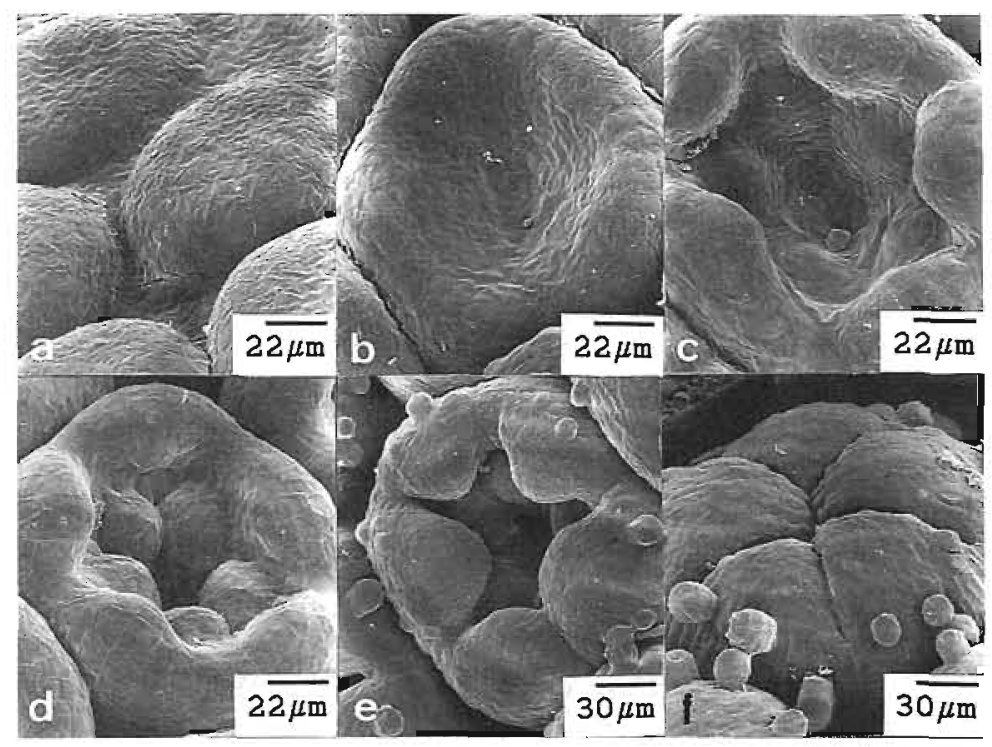

Fig. 3. Photomicrographs of developing of disc floret. a: Flattening of the disc floret dome. b: A primordium changes into concave shape. c: Initials of stamen primordia appear with the corolla. d: Elongation of stamens. e: The corolla initials elongate. f: Well-developed corolla (fused petal) primordia.

disc florets occupy more than half of the receptacle surface and can be distinguished from the ray florets. Disc florets are round or globular (Fig. $3 a)$, whereas the ray florets are triangular and accupy the basal one two layers between the central disc florets and the involucre.

At the early corolla-forming stage (Fig. 1-6), the receptacle apex (florets) becomes slightly depressed (concave). The developing floret cover about $80 \%$ of receptacle. The newly formed disc floret appears similar to that in Fig. 3. The older disc florets enlarge, remaining globular but be- come cup-shape as corolla differentiation takes place. Five stamens are initiated inside the corolla. The individual petal initials appear as small lobes on the margin which elongates slightly.

In the intermediate corolla-forming stage (Fig. 1-7), the advanced florets with a lobed corollas occupy nearly half of receptacle.

The late corolla-forming stage (Fig. 1-8) is reached when the older basal florets have well-developed corollas and cover more than half of the receptacle; the remaining disc florets are still differentiating floral parts. 
At anthesis, florets are fully developed; the petals of the ray florets expand fully (Fig. 1-9).

Cultivar differences on capitulum size, a number of ray and disc florets and involucres

There were cultivar differences in capitulum size, numbers of ray and disc florets and involucres (Table 1). The largest diameter of capitulum was $71.0 \pm 0.0 \mathrm{~mm}$ in 'Kabuhari' and the smallest one was $42.0 \pm 6.2 \mathrm{~mm}$ in 'Nantai chuba'. The number of ray florets ranged from $23.7 \pm 5.4$ in 'Oba-C' to $14.2 \pm 0.5$ in 'Chuba-C', whereas the disc florets ranged from $478.0 \pm 0.0$ in 'Oba-B' to $276.2 \pm 44.8$ in 'Kanto type kabuhari'. The largest number of bracts per involucre was $41.0 \pm 0.0$ in 'Oba-B' and the least was $27.5 \pm 5.0$ in 'Chuba- $A$ '. In general, the number of ray floret per capitulum was half that of the bracts.

Cultivar differences in flowering response in spring and autumn

Based on the number of days between planting and budding and anthesis, there were cultivar differences in flowering response between in spring and autumn. The interval between planting and budding for the all cvs. was shorter than that of autumn-grown seedlings. Capitulum of 'Kairyo chuba satoyutaka', 'Hakata kairyo chuba', 'Oedo', 'Chuba-A', 'Chuba-B', 'Obitsu', 'Yamabiko chuba', 'Chuba-C', 'Tatsunami', 'Kabuhari' and 'Oba' became visible $10 \sim 15$ days after planting in the spring, whereas those of 'Kabuhari chuba', 'Kiwame chuba', 'Nantai chuba', 'Koasa' and 'Otafuku' became visible more than 30 days after planting (Table 2).

In the autumn planting, the capitulum initiation of 'Kairyo chuba satoyutaka', 'Hakata kairyo chuba', 'Oedo', 'Chuba-A', 'Chuba-B', 'Obitsu', 'Tatsunami' and 'Kabuhari chuba' occurred at 70 days after planting (Fig. 4), whereas the buds of 'Kairyo chuba satoyutaka', 'Hakata kairyo chuba', 'Oedo', 'Chuba-B', 'Tatsunami' at 70 days after planting were still at stage 3 ; 'Chuba-A' and 'Obitsu' were stage 2 and the capitulum differentiation in 'Kiwame chuba', 'Kabuhari', 'Otafuku-A' and 'ObaA' had not occurred.

Node number from cotyledon to capitulum of all cultivars in the spring planting was less than that in the autumn planting, e.g. the number of nodes in 'Kairyo chuba satoyutaka' was only 32.8 in the spring (Table 2) but 54.7 in autumn (Fig. 4).

The differences in environmental factors in the

Table 1. Cultivar difference in floret, involucre number and size of capitulum in spring of 1995.

\begin{tabular}{|c|c|c|c|c|}
\hline \multirow{2}{*}{ No. Cultivar ${ }^{2}$} & \multicolumn{2}{|c|}{ No. of floret } & \multirow{2}{*}{$\begin{array}{l}\text { No. of } \\
\text { involucre }\end{array}$} & \multirow{2}{*}{$\begin{array}{l}\text { Capitulum } \\
\text { diameter } \\
(\mathrm{mm})\end{array}$} \\
\hline & Disc floret & Ray floret & & \\
\hline 1. Hakata kairyo chuba & $321.2 \pm 42.0$ & $20.7 \pm 0.5$ & $36.7 \pm 3.6$ & $49.5 \pm 8.2$ \\
\hline 2.Chuba-A & $291.0 \pm 53.7$ & $18.5 \pm 3.5$ & $27.5 \pm 5.0$ & $45.5 \pm 5.0$ \\
\hline 3. Chuba-B & $432.0 \pm 0.0$ & $21.0 \pm 0.0$ & $40.0 \pm 0.0$ & $51.0 \pm 0.0$ \\
\hline 4. Chuba-C & $242.2 \pm 8: 6$ & $14.2 \pm 0.5$ & $34.2 \pm 1.6$ & $49.6 \pm 3.0$ \\
\hline 5.Tatsunami & $313.0 \pm 12.7$ & $15.5 \pm 0.7$ & $31.0 \pm 0.0$ & $55.5 \pm 6.4$ \\
\hline 6. Kiwame chuba & $296.3 \pm 85.4$ & $15.5 \pm 3.7$ & $30.5 \pm 7.1$ & $60.3 \pm 8.8$ \\
\hline 7. Nantai chuba & $276.2 \pm 27.6$ & $20.2 \pm 0.8$ & $33.0 \pm 1.4$ & $42.0 \pm 6.2$ \\
\hline 8. Kyouwa chuba & $311.5 \pm 28.9$ & $16.5 \pm 1.4$ & $36.7 \pm 1.0$ & $58.2 \pm 3.8$ \\
\hline 9. Kairyou chuba & $336.0 \pm 23.4$ & $20.2 \pm 1.0$ & $38.2 \pm 1.8$ & $56.7 \pm 3.8$ \\
\hline 10. Kabuhari & $281.0 \pm 0.0$ & $20.0 \pm 0.0$ & $34.0 \pm 0.0$ & $71.0 \pm 0.0$ \\
\hline 11. Kanto type kabuhari & $276.2 \pm 44.8$ & $15.7 \pm 3.1$ & $32.5 \pm 3.1$ & $51.5 \pm 5.1$ \\
\hline 12. Oba-A & $299.7 \pm 15.2$ & $16.3 \pm 1.6$ & $32.5 \pm 1.1$ & $46.2 \pm 3.8$ \\
\hline 13. Oba-B & $478.0 \pm 0.0$ & $22.0 \pm 0.0$ & $41.0 \pm 0.0$ & $50.0 \pm 0.0$ \\
\hline $14 . \mathrm{Oba}-\mathrm{C}$ & $338.5 \pm 45.1$ & $23.7 \pm 5.4$ & $38.7 \pm 1.8$ & $52.2 \pm 7.4$ \\
\hline 15. Koji Oba (AVRDC) & $303.5 \pm 24.4$ & $17.7 \pm 2.7$ & $30.5 \pm 1.6$ & $57.5 \pm 2.6$ \\
\hline 16. Oba-D (China) & $309.2 \pm 23.4$ & $19.2 \pm 3.1$ & $34.7 \pm 4.4$ & $53.7 \pm 3.1$ \\
\hline
\end{tabular}


Table 2. Cultivar difference in budding date, date of anthesis and node number to capitulum in spring of 1992 .

\begin{tabular}{lccccc}
\hline \hline Cultivar & $\begin{array}{l}\text { No. of } \\
\text { budding }\end{array}$ & $\begin{array}{l}\text { No. of } \\
\text { anthesis }\end{array}$ & $\begin{array}{l}\text { Date of } \\
\text { budding }\end{array}$ & $\begin{array}{l}\text { Date of } \\
\text { anthesis }\end{array}$ & $\begin{array}{c}\text { No. of } \\
\text { nodes }\end{array}$ \\
\hline Kairyo chuba satoyutaka & 10 & 8 & $7 / 12$ & $7 / 27$ & 32.8 \\
Hakata kairyo chuba & 10 & 8 & $7 / 15$ & $7 / 29$ & 36.5 \\
Oedo & 11 & 11 & $7 / 15$ & $7 / 30$ & 42.1 \\
Chuba-A & 12 & 10 & $7 / 17$ & $8 / 2$ & 34.8 \\
Chuba-B & 9 & 3 & $7 / 19$ & $7 / 29$ & 54.0 \\
Obitsu & 6 & 8 & $7 / 20$ & $8 / 6$ & 41.5 \\
Yamabiko chuba & 8 & 7 & $7 / 20$ & $8 / 2$ & 40.7 \\
Chuba-C & 12 & 8 & $7 / 21$ & $8 / 10$ & 41.3 \\
Tatsunami & 11 & 9 & $7 / 22$ & $8 / 9$ & 45.3 \\
Kabuhari chuba & 4 & 1 & $8 / 4$ & - & 48.3 \\
Kiwame chuba & 10 & - & $8 / 5$ & - & 42.3 \\
Nantai chuba & 7 & 4 & $8 / 9$ & - & 45.8 \\
Koasa & 8 & 3 & $8 / 9$ & - & 48.1 \\
Kabuhari & 12 & 9 & $7 / 20$ & - & 44.3 \\
Otafuku-A & 8 & 3 & $8 / 9$ & - & 44.2 \\
Oba-A & 12 & 10 & $7 / 19$ & $7 / 29$ & 41.9 \\
\hline
\end{tabular}

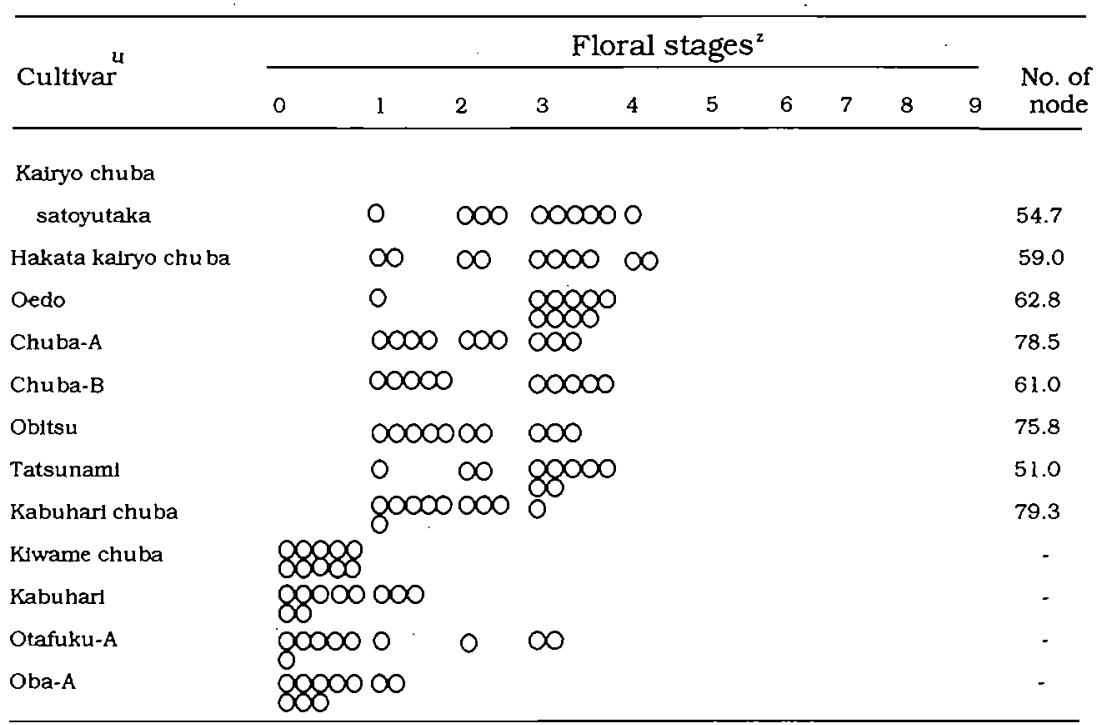

Fig. 4. Cultivar difference in flower bud initiation and node number to capitulum at 70 days after planting in autumn of 1991. $z$ : Refer to Fig. 1.

field, such as daylength and fluctuations in day/night temperatures between spring and autumn may affect the budding date and number of node to capitulum. The mean air temperatures in spring of 1991 and 1992 were $14.3^{\circ} \mathrm{C}$ and 17.7 ${ }^{\circ} \mathrm{C}$, respectively, whereas in autumn they were $26.8{ }^{\circ} \mathrm{C}$ and $20.1{ }^{\circ} \mathrm{C}$, respectively. The photo- period in spring was about $12 \mathrm{hr} 16 \mathrm{~min}$, whereas it was $11 \mathrm{hr} 39 \mathrm{~min}$ in the autumn. Therefore, budding was hastened at $14^{\circ}$ to $18{ }^{\circ} \mathrm{C}$ under a 12 hr photoperiod, compared to $20^{\circ}$ to $27^{\circ} \mathrm{C}$ and under a shorter photoperiod. This tendency is in agreement with the findings of Iwami et al. (1983) and Mochizuki and Hiraoka (1978) and our pre- 
vious investigation reported that capitulum initiation is promoted by low temperature under a long day condition (Yulian et al., 1994b, c).

\section{Literature Cited}

Bailey, L. H. 1949. Manual of cultivated plants. p. 987. Macmillan Publishing Co., New York.

Booij, R., E. J. J. Meurs, F. Thiel and A. Boekestein. 1992. Cryo-scanning electron microscopy of the apex of celeriac (Apium graviolens L. var. rapaceum (Mill). DC.) during initiation of inflorescence. Scientia Hortic. 51 : 309-320.

Brown, P. H. and R. C. Menary. 1994. Changes in apical morphology during floral initiation and develop. ment in pyrethrum (Tanacetum cinerariaefolium L.). J. Hort. Sci. $69: 181-188$.

Fujime, Y. 1983. Studies on thermal conditions of curd formation and development in cauliflower and broccoli, with special reference to abnormal curd development. Mem. Fac. Agr., Kagawa Univ. 40: $1-123$.

Herklots, G. A. C. 1972. Vegetable in South East Asia. p. 168-171. Asian Vegetable Research and Development Centre, Taipei.

Iwami, N., Y. Takahashi, E. Kosuge and S. Kurihara. 1983. Studies on the flower bud differentiation and bolting in some economic green vegetables. Bull. Tokyo Metropolitan Agr. Exp. Sta. 16 : $1-62$.

Javier, E. Q. 1990. Vegetable production training manual. p. 63. Asian Vegetable Research and Development Centre, Taipei.

Kakibuchi, K. 1994. Micromorphological and analytical studies on flower bud development and seed coat in some vegetable crops. Dr. Thesis. Ehime Univ., Ehime.

Larkcom, J. 1991. Oriental vegetables. p. 76-78. John Murray Ltd., London.
Mochizuki, M. and T. Hiraoka. 1978. Studies on internode elongation for garland chrysanthemum (Chrysanthemum coronarium L. var. spatiosum Bailey). 3 . Effect of photoperiods on internode elongation and flower bud differentiation, and effects of GA application on internode eleongation and flower bud differentiation. Bull. Kanagawa Agr. Exp. Sta. 120 : 1-13.

Morishita, M., K. Kida and K. Yamada. 1987. Selection of variety and environmental control for growth of garland chrysanthemum in summer. Bull. Osaka Agr. Res. Cent. $24: 67-75$.

Park, K. W. 1980. Chrysanthemum as vegetable. Gemuse $16: 398-400$.

Sagwansupyakorn, C., Y. Shinohara and Y. Suzuki. 1985. A study on the stage of flower initiation of Japanese radish using the scanning electron microscope. J. Japan. Soc. Hort. Sci. $54: 344-350$.

Shinohara, S. 1984. Vegetable seed production technology of Japan, elucidated with respective variety development histories, particulars. Vol. 1 p. 175-184. Yokendo, Tokyo.

Yulian, Y. Fujime and N. Okuda. 1994a. Flower bud development and branching property of garland chrysanthemum (Chrysanthemum coronarium L.). J. Japan. Soc. Hort. Sci. 63 (Suppl. 1): 326-327. (In Japanese).

Yulian, Y. Fujime and N. Okuda. 1994b. Effects of daylength and temperature on flower bud initiation and branching of garland chrysanthemum (Chrysanthemum coronarium L.). J. Japan. Soc. Hort. Sci. 63 (Suppl. 1): 328-329. (In Japanese).

Yulian, Y. Fujime and N. Okuda. 1994c. Effects of daylength on budding and branching property of garland chrysanthemum (Chrysanthemum coronar. ium L.). Japan. J. of Trop. Agr. 38 (Suppl. 2): 23-24. (In Japanese). 


\title{
シュンギクの頭状花序形成ならびに小花発育の形態観察
}

Yulian・藤目幸擴 - 奥田延幸

香川大学農学部 761-07 香川県木田郡三木町

\begin{abstract}
摘 要
シュンギク (Chrysanthemum coronarium L.) の頭状 花序形成ならびに小花の発達に扔ける形態を走查型電 子顕微鏡（SEM）を用いて調查した，早晩性の異なる 16 品種を供試した。花芽発達段階は 10 段階に分けら れた。頭状花序は総包分化前期に形成された。简状花 と舌状花との差異は小花形成後期から認められた. 筒 状花には 1 本の雌ずいと 5 本の雄ずいがあった。筒状 花は花床の全表面に形成された，1－2重の舌状花は 筒状花と総包の間に位置していた．舌状花に雌ずいは あったが，雄ずいはなかった。

頭状花序の直径, 筒状花ならびに舌状花之総包の数 には品種間で差が認められた。頭状花序の最大直径は $71.0 \pm 0.0 \mathrm{~mm}$ ('株張), 最小直径は $42.0 \pm 6.2 \mathrm{~mm}$ ('男体中葉”) であった。筒状花数と舌状花数の最大は， 1 花序当たりそれぞれ $23.7 \pm 5.4$ ('大葉ーB') と

$478.0 \pm 0.0$ ('大葉一B') であった，筒状花数と舌状 花数の最小は, 1 花序当たりそれぞれ $14.2 \pm 0.5$ ('中 葉 $-C^{\prime}$ ) と $276.2 \pm 44.8$ (“関東タイプ株張”)であっ た. 総包数の最大は $41.0 \pm 0.0$ (大葉一B')であり, 最小は $27.5 \pm 5.0$ ('中葉一A') であった。

春季と秋季に扔ける開花友応には，それぞれの品種 間で差が認められた，春季では，すべての品種が出ら いし，秋季に比べて早くなった，出らいは定植後，早 生種“改良中葉さとゆたがで10日，中生種‘たつなみ ’で15 日，晚生種“㧍多福一A'で35日となった。秋 季では, '改良中葉さとゆたか'は定植後70 日で花芽 を分化した，また，春季の着花節位は秋季に比べて影 著に低下した。改良中葉さとゆたがの着花節位は, 春季では 32.8 であったが, 秋季では 54.7 と高くなっ た.
\end{abstract}

